\title{
Elämänkaaritutkimus ja aikuiskasvatus
}

Yhteiskuntatieteissä on viime vuosina keskusteltu paljon elämäntavan kategoriasta ja tämä käsite on ollut peruslähtökohtana useissa tutkimuksissa. Näissä tutkimuksissa on selvitetty ansiokkaasti eri väestöryhmien elämäntapoja ja niitä yhteiskunnallisia tekijöitä, jotka ovat vaikuttaneet näiden elämäntapojen muotoutumiseen. Tällainen tutkimustieto on antanut aikuiskasvattajillekin konkreettista tietoa siitä yhteiskunnallisesta todellisuudesta, jossa aikuiset toimivat ja opiskelevat. Vähitellen on elämäntapatutkimuksissa siirrytty yhä enemmän yksityisten elämänhistorioitten tarkasteluun ja ihmisten toiminnan selitysmallien etsintään tästä näkökulmasta. Ongelmaksi tällöin on muodostunut se, voidaanko näitten yksilökohtaisten tarkastelujen perusteella tehdä mitään laajempia väestöryhmiä koskevia yleistyksiä.

Tämä näkökulman '"kaventuminen" on ilmeisesti seurausta yleisestä yhteiskunnassa tapahtuneesta privatisoitumiskehityksestä. Tätä taustaa vasten tarkasteltuna voidaan pitää luonnollisena, että aivan viime vuosina on tutkijoiden mielenkiinto kohdistunut yhä enemmän ihmisen elämänkaariproblematiikkaan. Tämä on tapahtunut samanaikaisesti useilla eri tieteenaloilla.

Edesmennyt amerikkalainen sosiologi Wright Mills on todennut vuonna 1959 ilmestyneessä kirjassaan, että 'Mikään yhteiskuntatieteellinen tutkimus, joka ei palaa elämänhistorian, historian sekä niiden leikkauskohtien ongelmiin, ei ole kulkenut taivaltaan päähän'’. Elämänkaariproblematiikassa on kysymys juuri tämäntapaisesta lähestymistavasta.

Elämänkaariproblematiikka soveltuu erityisen hyvin poikkitieteellisen tutkimuksen lähtökohdaksi, sillä siinä yhdistyvät yksilön kehityksen fysiologiset, psykologiset, sosiaalipsykologiset, kasvatustieteelliset sekä sosiologiset kysymykset yhtenäiseksi ongelmakimpuksi, jota pyritään tarkastelemaan historiallisesta perspektiivistä. Kysymys on siis ihmisen ja hänen elämänhistoriansa tutkimisesta tietyissä ajallisissa rajoissa. Tämä problematiikka liittyy tavalla tai toisella kaikkeen yhteiskuntatieteelliseen tutkimukseen.

Perustan elämänkaaritutkimukselle antaa ihmisen fysiologisen kehityksen tutkimus, johon läheisesti liittyy myös persoonallisuus- ja oppimispsykologinen tutkimus. Aikuiskasvatuksen kannalta erityisen mielenkiintoisia ovat olleet sellaiset oppimispsykologiset tutkimukset, joissa on selvitetty eri ikäisten henkilöiden oppimista erilaisissa tilanteissa ja erilaisen oppiaineksen kyseenollessa. Edellä mainitut lähestymistavat edustavat elämänkaaritutkimuksessa yksilöllistä näkökulmaa. Myös historiallis-yhteis- 
kunnallisilla tekijöillä on vaikutuksensa yksilön elämänkaaren muotoutumiseen. Havainto että eri aikoina syntyneet henkilöstöryhmät eroavat huomattavasti toisistaan kohraloittensa ja yhteiskunnallisen kokemuksensa suhteen, on ohjannut ikääntymisen tutkijoita eri aikoina syntyneiden ikäluokkien elämänkaarien vertailuun. Vasta tällainen historiallis-yhteiskunnallinen tarkastelu liittää elämänkaaritutkimuksen konkreettiseen todellisuuteen.

Ikääntymistä voidaan ja tulee tutkia monen eri tieteenalan piirissä. Näiden tutkimustulosten hyväksikäyttö on kuitenkin ollut vaikeaa, koska tuloksia ei ole koottu yhtenäiseksi kokonaisuudeksi. Tämä olisi ainakin aikuiskasvatusta ja aikuiskasvattajia ajatellen tärkeä tehtävä. On merkillepantavaa, että muillakin tahoilla on havaittu tämä puute. Tästä on osoituksena vuonna 1980 perustettu Kasvun ja vanhenemisen tutkijat -yhdistys, joka on koonnut yhteen laajan joukon ikääntymisen ongelmasta kiinnostuneita eri tieteenalojen edustajia. Tulevaisuus näyttää, millaisia tuloksia tämä yhteistyö tuottaa. Alku ainakin näyttää lupaavalta.

On luonnollista, että elämänkaariproblematiikka on aina kiinnostanut aikuiskasvattajia, sillä muodostaahan opiskelijantuntemus koko toiminnan lähtökohdan. Tietysti se on kaikessa muussakin opetustoiminnassa merkityksellinen, mutta aikuiskasvatuksessa se on erityisen keskeinen kahdesta syystä. Ensinnäkin, aikuisten elämänkohtalot ja -kokemukset sekä opiskelumahdollisuudet vaihtelevat huomattavasti. Tämä aiheuttaa opetuksen järjestämiselle monia ongelmia. Toiseksi, opiskelijoiden tietotasoa sekä oppimiskykyä ja -tyyliä koskevat virhearvioinnit voivat johtaa opetuksen täydelliseen epäonnistumiseen. Opettaja voi joutua pian puhumaan tyhille seinille.

Vaikka aikuiskasvatuksessa usein korostetaan opiskelijakeskeisyyttä didaktisena lähtökohtana, niin käytännössä se jää usein pelkäksi fraasiksi. Tämä ei varmaankaan johdu siitä, etteivät aikuisopettajat haluaisi ottaa tätä periaatetta huomioon, vaan siitä, että heiltä tavallisesti puuttuu aikuisen syvällinen fysiologinen, kehityspsykologinen ym. tuntemus. Tässä suhteessa aikuiskasvattajat asettavat suuria odotuksia nyt virinneeseen kiinnostukseen ihmisen kasvu- ja vanhenemistapahtuman tutkimusta kohtaan. Toivottavasti se tuottaa myös sellaista tietoa, jota aikuiskasvattajat voivat käyttää hyväkseen opetustoimintaansa kehittäessään. Tämän lehden artikkelit pyrkivät osaltaan täyttämään tätä tarvetta. 